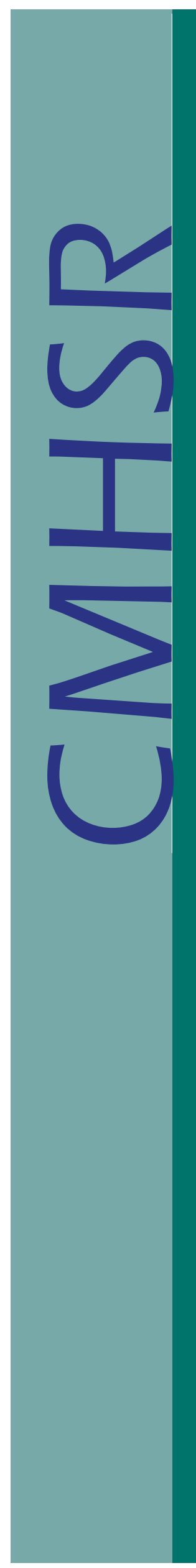

April 2005

\title{
Youth Transitioning to Adulthood: Effects of Different Population Policies in Child and Adult Mental Health Service Systems
}

\section{Issue

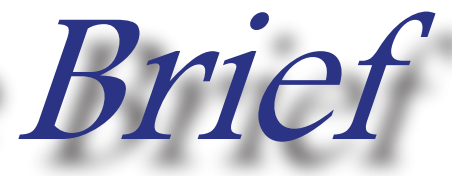

Maryann Davis, Ph.D. ${ }^{1}$ and Nancy Koroloff, Ph.D. ${ }^{2}$

1

The transition from adolescence into adulthood is a period of rapid psychosocial development that underlies the acquisition of the skills and capacities to function as adults. For young people with serious mental health $(\mathrm{MH})$ conditions, the movement into adulthood is precarious. Most adolescents with psychiatric disorders continue to have those disorders in young adulthood. Psychiatric disorders during the transition to adulthood, roughly ages 16-30, seriously impede the development of adult role functioning. These ages span those served by state child and adult $\mathrm{MH}$ systems. For adolescents in child $\mathrm{MH}$ and young adults in adult MH systems, continuity of care and the provision of age-appropriate supports are needed to assist them in their quest for adult functioning.

One challenge to the continuity of care across child and adult $\mathrm{MH}$ systems may stem from differing population policies. Population policies are those that define a system's eligible or target population. The important questions for transition-aged youth include: Do population policies used in the adult $\mathrm{MH}$ system differ from those used in the child MH system? If so, does this restrict access to services for adolescents aging out of the child MH system? This brief describes a study which examined these questions by comparing the population policies of child and adult state MH systems.

\section{Study of Population Policies}

State child and adult MH population policies were requested from members of the National Association of State Mental Health Program Directors. Policies were current as of June 2003. This analysis is based on the 45 states, and the District of Columbia which

(c) 2005 Center for Mental Health Services Research

Department of Psychiatry submitted both child and adult policies.* Policies were compared to determine if, and how, states' adult policies exclude individuals who fit child policies. All policies were examined and coded for criteria, such as the requirement of a diagnosable psychiatric disorder. Analyses of fiscal requirements are not included as these criteria were not consistently described in the submitted policies.

\section{Findings}

In general, state child population policies were less restrictive and no state had an identical child and adult policy.

Most state child MH services ended at age 18 (31 states), with a smaller number continuing to age 21 (12 states) and one state each continued to age 19 and 22. Age criteria were missing for one state. All state adult MH systems but one served those 18 and older.

Table 1 summarizes the comparison between child and adult policies across 46 states. More adult policies than child policies used diagnostic criteria, more narrow diagnostic criteria, and functional criteria to determine their eligible or target population. In addition, several adult and child population policies used other criteria to define their population including: being at risk or a history of out-of-home placement or other intensive services (13 child, 17 adult policies); the presence of or risk for psychosis or dangerousness to self or others ( 7 child, 6 adult policies); multiagency or interdisciplinary team involvement (9 child, 0 adult policies); being a special education student (4 child, 0 adult policies); being homeless and mentally ill ( 2 child, 5 adult policies); and other criteria (16 child, 13 adult policies).

* the 45 states plus the District of Columbia, for brevity purposes, will be referred to simply as "states" throughout. 
Table 1: Frequency of Condition Requirements of Adult and Child Population Policies

\begin{tabular}{|c|c|c|c|c|}
\hline \multirow{2}{*}{ Criteria } & \multirow{2}{*}{ Value } & \multicolumn{2}{|c|}{ \# of State Policies } & \multirow{4}{*}{$\begin{array}{l}\text { * Policy stipulates } \\
\text { that this condi- } \\
\text { tion qualifies, but } \\
\text { is not required if } \\
\text { other conditions } \\
\text { are met. } \\
* * \text { Summarizes } \\
\text { whether or not a } \\
\text { functional impair- } \\
\text { ment, however } \\
\text { it is defined, is } \\
\text { required. }\end{array}$} \\
\hline & & Child & Adult & \\
\hline $\begin{array}{l}\text { 1. Requirement of DSM- } \\
\text { IIIR /-IV diagnosis, or } \\
\text { ICD equivalent ( } \mathrm{n}=46)\end{array}$ & $\begin{array}{r}\text { Yes } \\
\text { No } \\
\text { This or other conditions qualify* }\end{array}$ & $\begin{array}{r}35 \\
8 \\
3\end{array}$ & $\begin{array}{r}43 \\
1 \\
2\end{array}$ & \\
\hline $\begin{array}{l}\text { 2. Included diagnoses } \\
\text { when diagnoses were } \\
\text { required or qualified } \\
\text { (Child } N=38 \text {, Adult } N=43 \text { ) }\end{array}$ & $\begin{array}{r}\text { Psychotic disorders } \\
\text { Major affective disorders } \\
\text { Borderline personality disorder } \\
\text { Post traumatic stress disorder } \\
\text { Attention deficit/disruptive behavior disorders }\end{array}$ & $\begin{array}{l}38 \\
38 \\
38 \\
35 \\
37\end{array}$ & $\begin{array}{l}43 \\
43 \\
33 \\
28 \\
18\end{array}$ & \\
\hline $\begin{array}{l}\text { 3. Requirement of func- } \\
\text { tional impairment }{ }^{* *}(n=46)\end{array}$ & $\begin{array}{r}\text { Yes } \\
\text { No } \\
\text { This or other conditions qualify* }\end{array}$ & $\begin{array}{r}29 \\
3 \\
14\end{array}$ & $\begin{array}{r}36 \\
3 \\
7\end{array}$ & \\
\hline
\end{tabular}

A comparison between child and adult mental health population policies within each state was conducted to address the question of whether adolescents who qualified for services under the child policy would continue to qualify for services within the adult system. Thirty states had more restrictive adult psychiatric diagnostic criteria, and seven states had more restrictive adult functional impairment criteria. For the remaining nine states there was some other condition that varied between the two policies.

\section{Implications}

These findings indicate that a portion of the child $\mathrm{MH}$ population does not qualify for the adult population policy in every state. Hypothetically, this has both direct and indirect effects on the transitioning population. The direct effect is that some young people who have continuing service needs will be denied any further state mental health services once they age out of the child MH system. Indirectly, services designed under population policies with such sharp age delineation may result in adult services that do not accommodate the developmental needs of young adults.

\section{Policy Recommendations}

Fortunately, there are a number of policy recommendations which would greatly improve the current disparity problems and remove arbitrary barriers created by definitional differences between the adult and child MH systems.

- Grandfathering of eligibility for child MH clients for entry into adult services. This remedy currently exists within some state policies.

- Align child and adult policies so that the criteria are the same, ideally by being more inclusive than exclusive.

- Broaden population policies so individuals under age 30 who matched either the child or adult policy would be considered part of the target or eligible population. This solution would be most fair, and remove the most arbitrary barriers.

1 Center for Mental Health Services Research

2 Regional Research Institute for Human Services, Portland State University

\section{Relevant Readings}

Settersten, R. Jr., Furstenberg, F. Jr., \& Rumbaut, R. (Eds.) (2005). On the frontier of adulthood: Theory, research, and public policy. Chicago:University of Chicago Press.

Davis, M., \& Hunt, B. (in press). State Efforts to Expand Transition Supports for Young Adults Receiving Public Adult Mental Health Services. Rockville, MD: Substance Abuse and Mental Health Services Administration, Center for Mental Health Services.

Davis, M., \& Vander Stoep, A. (1997). The transition to adult hood among children and adolescents who have serious emotional disturbance Part I: Developmental transitions. Journal of Mental Health Administration, 24(4), 400-427.

Hechtman, L. (Ed.) (1996). Do they grow out of it? Long-term outcomes of childhood disorders. Washington, DC: American Psychiatric Press.

Kessler, R. C., Foster, C. L., Saunders, W. B., \& Stang, P. E. (1995). Social consequences of psychiatric disorders I: Educational attainment. American Journal of Psychiatry, 152(7), 1026-1032. 